\title{
Are Canadian professors teaching the skills and knowledge students need to prevent plagiarism?
}

\author{
Martine Peters ${ }^{*}$ (i) and Alain Cadieux
}

\author{
* Correspondence: martine.peters@ \\ uqo.ca \\ Université du Québec en Outaouais, \\ 283, boulevard Alexandre-Taché, \\ C.P. 1250, succursale Hull, Gatineau \\ (Québec) J8X 3X7, Canada
}

\begin{abstract}
Max 150 words. If possible, please submit your abstract in both English and French. When writing an assignment, most students start by searching for information online, which they integrate in their writing and conclude by producing a bibliography for the sources used. They use their informational, writing and referencing skills to do this as well as refer to their plagiarism knowledge to make sure their text is exempt from plagiarism. In this paper, we examined which skills and knowledge students feel the need to further develop in university to prevent plagiarism in their assignments. Professors were also questioned as to their perceptions of their students' skills development during their pre-university studies. Questionnaires were administered in six Quebec Universities to students $(n=1170)$ and professors $(n=279)$. Results show that students feel the need for more training while professors expect students to have already mastered the skills and knowledge to prevent plagiarism. Recommendations are made on how to implement better training for students through a program approach.

Lors de la rédaction d'un devoir, la plupart des étudiants universitaires commencent par chercher des informations en ligne, qu'ils intègrent dans leur rédaction et terminent en produisant une bibliographie des sources utilisées. Ils utilisent leurs compétences informationnelles, rédactionnelles, et de référencement documentaire et se réfèrent à leurs connaissances en matière de plagiat pour s'assurer que leur texte en soit exempt. Dans cet article, nous avons examiné les compétences et les connaissances que les étudiants ressentent le besoin de développer davantage à l'université pour prévenir le plagiat dans leurs travaux. Les professeurs ont également été interrogés sur leur perception du développement des compétences de leurs étudiants durant leurs études pré-universitaires. Des questionnaires ont été administrés dans six universités québécoises à des étudiants $(n=1170)$ et à des professeurs $(n=279)$. Les résultats montrent que les étudiants ressentent le besoin d'une formation plus poussée alors que les professeurs s'attendent à ce que les étudiants maîtrisent déjà les compétences et les connaissances nécessaires pour prévenir le plagiat. Des recommandations sont formulées sur la façon de mettre en œuvre une meilleure formation pour les étudiants par le biais d'une approche-programme.
\end{abstract}

Keywords: Digital scrapbooking strategies, Informational skills, Writing skills, Referencing skills, Plagiarism 


\section{Maintext}

In the last two decades, university students writing habits have changed drastically with the event of technology and the web (Moore et al., 2016). They have almost stopped researching in university libraries (Biddix et al., 2011; Leeder \& Shah, 2016) and have become heavily dependent to the web and Google when it comes to looking for information (Head \& Eisenberg, 2010). A favorite action has become copying and pasting (Sutherland-Smith, 2018). Unfortunately, these new habits have resulted in a dramatic increase in plagiarism in universities all over the world (Amiri \& Razmjoo, 2016; Janssens \& Tummers, 2015).

Researchers have deplored the fact that students do not receive the necessary training to understand and prevent plagiarism (Holt, 2012; McGowan \& Lightbody, 2008). Students themselves feel they lack academic literacies and confidence on entering universities (Palmer et al., 2018). However, few researchers have examined with which training or which skills are necessary to write assignments with integrity.

Peters (2015) has proposed a theoretical model which includes informational, writing and referencing skills as well as the digital scrapbooking strategies mobilized by these skills can help prevent plagiarism. According to this researcher, students need to develop these skills and strategies, before and at university, in order to be able to write a coherent text, exempt of plagiarism (Peters et al., 2019). In this paper, we will present this model as well as results from students and professors questionnaires showing how there is a disconnect between the training the students would like to receive and the training they are likely to get.

\section{Conceptual framework}

When writing an assignment, most students start by looking for information online (Becker, 2016), then will incorporate this information in their writing "to demonstrate their knowledge" (Cronin, Ryan, \& Coughlan, 2008, p. 41) and conclude by producing a bibliography for the sources used (Ramdhani, Ramdhani, \& Amin, 2014). Digital scrapbooking is the process used by students to collect, assemble, copy and paste, various pieces of information on the web such as ideas, texts, images, and videos. Students then reformulate and recontextualize the material and weave it together in a new creation in which credit is given to the authors of the original information (Peters \& Gervais, 2016). Other authors have referred to this process as patchworking which is identified as a technique used by second language or novice writers who have difficulties in writing a text because of their language limitations (Howard, 1995; Pecorari, 2015). Digital scrapbooking goes well beyond patchwork, it is a process that is constructive and evolving and it is used by many writers, from beginners to experts.

Peters' theoretical model (Fig. 1) shows the interaction between the strategies and the skills. When searching for information, students will identify their topic, search with a variety of tools and look at different sources, sifting through the information. Some students will choose to search for their information at the beginning while others will continue to search while writing. The information needs to be organized, connecting it together with the students' own ideas and opinions. When integrating the information in the text, paraphrases and quotes can be used by the students. Some students will 


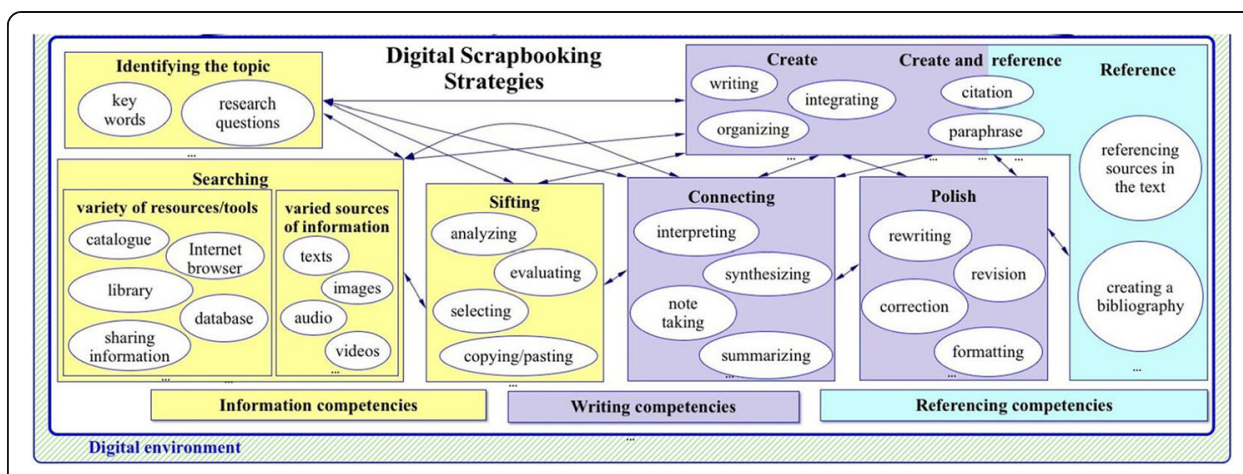

Fig. 1 Peters model of digital scrapbooking strategies and the skills used by

indicate their sources as they write while others will create their bibliography at the end of the process.

Digital scrapbooking strategies are mobilized by three sets of skills: informational, writing and referencing skills. These strategies are actions to support these skills, and can be used at any time during the process of producing the assignment. Students will use assorted skills and strategies, in a different sequence since the process can vary from student to student according to their skill level, the task required and their preferences.

\section{Informational skills defined}

Informational skills were first defined as the ability to search efficiently for information (Bawden, 2001). However, computers and in particular the internet changed our relationship to information, making it readily available to those with computer skills (Crockett, Jukes, \& Churches, 2011). Informational skills were redefined to include metacognitive (Mackey \& Jacobson, 2011) and ethical dimensions (Catts \& Lau, 2008).

"Information literacy is the set of integrated abilities encompassing the reflective discovery of information, the understanding of how information is produced and valued, and the use of information in creating new knowledge and participating ethically in communities of learning" (Association of College and Research Libraries, 2016, p. 3).

And so, informational skills are not limited to the procedural and technical capacity to find information on the web, they also require a series of complementary skills that involve critical thinking, analysis (R. Harris, 2013; Simonnot, 2007), interpretation of information according to one's own needs, with the ultimate goal of making an evaluative decision about the information collected (American Association of School Librarians, 2007), and the skills needed to manage, create, reference and share information (Jeffrey et al., 2011; Nelson, Courier, \& Joseph, 2011).

\section{Whose responsibility is it to teach about informational skills?}

While Kargbo (2010) has found that students judge their informational skills to be sufficient for their needs, other researchers have found that students need more training to further develop their informational skills in order to properly evaluate and use the information collected (Brand-Gruwel, Kammerer, van Meeuwen, \& van Gog, 2017; Rodicio, 2015; Serres, 2012; Steeves, 2014). According to Roy (2009), many students 
would like their teachers to train them in order to be better able to assess the relevance, value and credibility of the information they find on the web.

Unfortunately, it seems that teaching about informational skills is not officially on anyone's curriculum at the university level (Dawes, 2017) and that professors have a NIMBY approach "not in my back yard attitude" to teaching these skills (Bury, 2011). Many librarians offer workshops but they are what Artman, Frisicaro-Pawlowski, and Monge (2010, p. 94) call.

"one-shot-instruction to describe brief (50-75 minute) library sessions in which they are asked to teach students all the skills they need to become information literate".

Julien, Gross, and Latham (2018) explain in their research how librarians deplore the fact that there is little buy-in from students and their professors on the importance of informational skills.

Even though there seems to be a lot of research that shows that professors do not systematically teach informational skills but prefer to leave this task to librarians (Goldenstein \& Kearley, 2013; Kissel et al., 2016; Saunders, 2012), there are a few studies that show otherwise (Bury, 2011, 2016; DaCosta, 2010; Dubicki, 2013). However, it seems that professors are not primarily concerned by the development of informational skills in their students but are more preoccupied with helping "students understand how researchers think and behave, and to cultivate in the students an attitude to information that impacts their behaviour and their approach to learning the subject content" (Dawes, 2017, p. 558).

\section{Writing skills defined}

Hayes and Flower's model (1980) has defined the writing process for many decades as an iterative sequence of high-level processes such as planning, writing and editing (Didier, 2017). Thus, writing skills involve being able to employ these processes but also use them in diverse settings (in class, at home, on the web), with the appropriate genre (lab report, letter, portfolio, etc.) and modalities (script, numerical, prescribed time) (Tassin \& Spanghero-Gaillard, 2017). A skilled writer will be able to adjust to all these constraints (Wischgoll, 2016).

At the university level, students must also learn how to write in two different styles: academic writing and disciplinary discourse (Delcambre \& Lahanier-Reuter, 2010). New students are therefore confronted with new editorial requirements, while at the same time having to appropriate the bodies of knowledge related to the discipline they have chosen (Foster, 2002). Furthermore, students must meet their professors' requirement for original thinking (Medvedeva \& Recuber, 2016) and the obligations to refer to the sources consulted (Hyland, 2015). University students who rely heavily on information found on the web must weave into their own writing with quotes and paraphrases to show how they have acquired new knowledge (Beaudet, 2015). Many students have come to appreciate the extra aid given by online dictionaries (Peters, Weinberg, Sarma, \& Frankoff, 2011), spellcheck tools (Conole et al., 2008) and even paraphrasing software (Prentice \& Kinden, 2018; Rogerson \& McCarthy, 2017).

But whose responsibility is it to teach writing skills at university? Many institutions have implemented writing centers (Isaacs \& Knight, 2014) while others have built programs such as "Writing Across the Curriculum" (Defazio, Jones, Tennant, \& Hook, 2010) or "Writing in the Disciplines" (Goldschmidt, 2014; Ovadia, 2010), or programs offered to 
students who are not native speakers such as English for academic purposes (Wingate \& Tribble, 2012) or English for specific purposes (McGrath \& Kaufhold, 2016).

These programs are usually the responsibility of learning centers or language instructors who rarely engage with discipline professors (A. Harris, 2016). While these programs are worthwhile, several authors insist on the fact that writing must be embedded across all university curriculum and available to all types of students (Lea, 2004; Murray \& Nallaya, 2016; Strangfeld, 2019), because of the complexity of these skills and their importance to academic success (Richards \& Pilcher, 2018). But as Wingate and Tribble (2012) explain, in order to integrate the teaching of writing with the teaching of disciplines, the subject professor must be very involved. Unfortunately, as certain authors (Peters, Boies, \& Morin, in press; Wingate, 2006) have mentioned, this would involve "the mountainous task of securing the commitment of all academics teaching in degree courses" (Fenton-Smith et al., 2017, p. 465).

\section{Referencing skills defined}

Referencing skills refer to knowing when, how and why quoting and paraphrasing an author is necessary (Vardi, 2012). Students who have developed referencing skills show their understanding of the authors they have read (Shi, 2010) while at the same time, giving the information necessary to find these authors (Rekdal, 2014) and showing they respect intellectual property (Duplessis \& Ballarini-Santonocito, 2007).

Hutchings (2014) has mentioned that students must be trained to reformulate the ideas they read. However, Vardi (2012) specifies that students' difficulties to paraphrase often come from the lack of knowledge from their field of study and so referencing skills must be closely linked to the development of this knowledge and its specific vocabulary (Hutchings, 2014).

Students would also greatly benefit from referencing software training since research has shown that few of them use this type of software (Milewski \& Williamson, 2017; Salem \& Fehrmann, 2013). This would prevent them from making mistakes they often commit when referencing their sources according to norms (Mandernach, Zafonte, \& Taylor, 2016), or when quoting and paraphrasing (Newton, 2016).

Referencing skills are often viewed as a mechanical process, not very difficult to learn (Buckley, 2015). However, that is far from the truth according to Gravett and Kinchin (2018, p. 1) who insist that "referencing has become a critical but often opaque academic convention, and an area of practice imbued with issues of power, identity and non-belonging". Professors must teach referencing skills by explaining to students the concepts of authorship and ownership as well as effective ways to use information in a text with critical objectivity, to prove the merits of arguments by establishing links between authors (Buckley, 2015; Liardét \& Black, 2016).

\section{Methodology}

Online questionnaires were administered in six Quebec universities in the fall and winter semester of 2017 (Peters, Vincent, Fontaine, \& Fiset-Vincent, 2018). The questionnaire contained 66 questions and took about $15 \mathrm{~min}$ to complete. For the purpose of this article, results from only five questions will be presented.

Student participants were asked to rate with two different Likert scales (frequency, agreement), questions about their information, writing, writing skills as well as their 
plagiarism knowledge. Faculty had a slightly different version of the questionnaire, asking them questions about which skills and knowledge they taught as well as their perceptions about their students' skills and knowledge. Both questionnaires had a final section with demographic questions.

\section{Student participants}

The student participants were from six Quebec universities $(n=1170)$. They were undergraduate students from various disciplines, mostly in Education (25\%), Sciences (25\%) and Human and social sciences (26\%) with $24 \%$ of the participants who did not specify. The average age was 26 years old with more than $60 \%$ of the participants between the ages of 20 and 29. More women $(n=732,62 \%)$ than men $(n=209,18 \%)$ answered the questionnaire but a good proportion of participants declined to answer the question $(n=229,20 \%)$. The questionnaire did not contain a question about the university level of students. This might have produced a more nuanced analysis and could be included in further research.

\section{Faculty participants}

Faculty participants were from the same universities as the students. In total, 279 faculty members answered the questionnaire. Of those, 113 were women (41\%), 87 were men (31\%), and 79 participants (28\%) chose not to answer the gender question. The faculty participants were between the ages of 28 and 71 with the average being 45 years old. The largest group of participants came from the field of Education (25\%), followed by Sciences (24\%) and Human and social sciences (19\%) and 32\% of the participants did not specify their field of expertise.

\section{Results}

Four questions were asked to students about their need for further training to develop their informational, writing and referencing skills as well as knowledge to prevent plagiarism. The fifth question asked them if they thought they were competent when it came to academic writing. Professors were asked the equivalent five questions, about teaching the skills and the knowledge, and their perceptions of their students' writing competence.

Informational skills development for students and professors' expectations of those skills A very large percentage of students completely agreed or mostly agreed that they expected to further develop their informational skills at the university. Only $0.9 \%$ of the students felt they did not need any training for the informational skills (see Table 1). Only $2.8 \%$ of the students disagreed with the statement whereas $94 \%$ of the students agreed with it.

As for faculty, $90 \%$ of them agree to different degrees that students should have developed their informational skills before they arrive at the university (see Table 2). Only $8,6 \%$ of them disagree with the statement. There is a very large discrepancy between what the students expect to learn and what the professors think students have already learned. 
Table 1 Students' expectations for the development of their informational skills

\begin{tabular}{lll}
\hline $\begin{array}{l}\text { l expect to further develop my informational skills (information research, formulating keywords, using search } \\
\text { engines, etc.) during my university studies. }\end{array}$ & Frequency & Percentage \\
\hline Completely disagree & 11 & 0,9 \\
Mostly disagree & 9 & 0,8 \\
Slightly disagree & 13 & 1,1 \\
Neutral & 37 & 3,2 \\
Slightly agree & 73 & 6,2 \\
Mostly agree & 258 & 22,1 \\
Completely agree & 769 & 65,7 \\
Total & 1170 & 100,0 \\
\hline
\end{tabular}

\section{Writing skills development for students and professors' expectations of those skills}

Students' expectations for the development of their writing skills is higher than for their informational skills. Almost $70 \%$ of the students completely agree that they need further training for their writing skills, with a total of $95,6 \%$ who agree to different degrees with the statement (see Table 3).

As for the professors' expectations of their students' writing skills, these are even higher than for the informational skills (see Table 4). The percentage of professors (93, $2 \%$ ) who expect students to have developed their writing skills prior to university is almost the same as the percentage of students $(95,6 \%)$ who expect to further develop their writing skills during their studies (see Table 3).

\section{Referencing skills development for students and professors' expectations of those skills}

As for the other two skills, students expect to develop their referencing skills while completing their studies (see Table 5). The level for all degrees of agreement for the referencing skills $(94,7 \%)$ is slightly lower than for the writing skills $(95,6 \%)$ while approximately the same for the informational skills (94\%).

The professors' expectations of their students' referencing skills is lower than for their writing skills (93,2\%) and informational skills (90\%). Only 82,9\% of professors agree that students have developed referencing skills prior to university (see Table 6). And so this

Table 2 Professors' expectations of their students' informational skills

As a professor or lecturer, I expect undergraduate students to have sufficiently developed their informational skills (information research, formulating keywords, using search engines, etc.) during their pre-university studies to be functional at the university.

\begin{tabular}{lll}
\hline & Frequency & Percentage \\
\hline Completely disagree & 3 & 1,1 \\
Mostly disagree & 11 & 3,9 \\
Slightly disagree & 10 & 3,6 \\
Neutral & 4 & 1,4 \\
Slightly agree & 53 & 19 \\
Mostly agree & 85 & 30,5 \\
Completely agree & 113 & 40,5 \\
Total & 279 & 100,0 \\
\hline
\end{tabular}


Table 3 Students' expectations for the development of their writing skills

\begin{tabular}{lll}
\hline $\begin{array}{l}\text { l expect to further develop my writing skills (writing, correcting, editing, quoting and paraphrasing) during my } \\
\text { university studies. }\end{array}$ & Frequency & Percentage \\
\hline Completely disagree & 7 & 0,6 \\
Mostly disagree & 6 & 0,5 \\
Slightly disagree & 13 & 1,1 \\
Neutral & 25 & 2,1 \\
Slightly agree & 73 & 6,2 \\
Mostly agree & 238 & 20,3 \\
Completely agree & 808 & 69,1 \\
Total & 1170 & 100,0 \\
\hline
\end{tabular}

is contradictory to students who expect less training for their referencing skills while their professors expect them to need more training for those same skills.

\section{Plagiarism knowledge for students and professors' expectations of this knowledge}

The area where students feel the need for less training is to acquire knowledge about plagiarism. While fewer students feel this need, there are still $85,1 \%$ who agree, to various degrees, that they need to be trained to avoid plagiarism (see Table 7).

As for professors, most of them expect students to have been trained prior to their university studies on how to prevent plagiarism. The percentage of professors $(89,6 \%)$ who agree to various degrees is almost the same as the students who wish to be trained on how to avoid plagiarism (see Table 8 ). This leaves only approximately $10 \%$ of professors who feel that students need training in plagiarism prevention.

\section{Students and professors' perception of academic writing}

While students feel the need for more training as shown in the previous tables, $47,4 \%$ mostly agree that they are comfortable with academic writing while another 28,5\% completely agree with the statement (see Table 9). A smaller percentage $11,2 \%$ slightly agree while $11 \%$ are neutral or disagree with the statement.

Table 4 Professors' expectations of their students' writing skills

\begin{tabular}{lll}
$\begin{array}{l}\text { As a professor or lecturer, I expect undergraduate students to have sufficiently developed their writing skills } \\
\text { (writing, correcting, editing, citing and paraphrasing) during their pre-university studies to be functional at the } \\
\text { university. }\end{array}$ & Frequency & Percentage \\
\hline & 3 & 1,1 \\
\hline Completely disagree & 9 & 3,2 \\
Mostly disagree & 5 & 1,8 \\
Slightly disagree & 2 & 0,7 \\
Neutral & 36 & 12,9 \\
Slightly agree & 98 & 35,1 \\
Mostly agree & 126 & 45,2 \\
Completely agree & 279 & 100,0 \\
Total & & \\
\hline
\end{tabular}


Table 5 Students' expectations for the development of their referencing skills

\begin{tabular}{lll}
\hline $\begin{array}{l}\text { I expect to further develop my referencing skills (build a bibliography, know the standards of presentation, etc.) } \\
\text { during my university studies. }\end{array}$ & Frequency & Percentage \\
\hline Completely disagree & 7 & 0,6 \\
Mostly disagree & 9 & 0,8 \\
Slightly disagree & 15 & 1,3 \\
Neutral & 32 & 2,7 \\
Slightly agree & 86 & 7,4 \\
Mostly agree & 264 & 22,6 \\
Completely agree & 757 & 64,7 \\
Total & 1170 & 100,0
\end{tabular}

As for faculty, they seem to disagree with the students' perception of their level of comfort as can be seen in Table 10 .

While $11 \%$ of students divulge the fact that they are not comfortable with academic writing, more than $42 \%$ of professors think that students are not comfortable with academic writing. The levels of agreement between students and professors also vary greatly. While $11,2 \%$ of students slightly agree, $27,6 \%$ of professors share that level of agreement and the discrepancy is even higher for the mostly agree category with $47,4 \%$ of students for only $27,6 \%$ of professors. Finally, while $28,5 \%$ of students completely agree with the statement that they are comfortable with academic writing, only $0,7 \%$ of professors completely agree that their students are comfortable with this type of writing.

\section{Discussion}

Looking at the student's data, it is possible to confirm that students expect to improve their informational, writing and referencing skills as well as learn more about how to prevent plagiarism in their work. These students have been through 13 years of schooling before their reach university yet they feel that they need more training to be able to fulfill the requirements of university. This confirms what other authors have said about the necessity of further training for informational (Probert, 2009; Shao \& Purpur, 2016), writing (Burgess-Proctor, Cassano, Condron, Lyons, \& Sanders, 2014; Pelger \&

Table 6 Professors' expectations of their students' referencing skills

As a professor or lecturer, I expect undergraduate students to have sufficiently developed their referencing skills (build a bibliography, know the standards of presentation, etc.) during their pre-university studies to be functional at the university.

\begin{tabular}{lll}
\hline & Frequency & Percentage \\
\hline Completely disagree & 13 & 4,7 \\
Mostly disagree & 19 & 6,8 \\
Slightly disagree & 11 & 3,9 \\
Neutral & 5 & 1,8 \\
Slightly agree & 54 & 19,4 \\
Mostly agree & 102 & 36,6 \\
Completely agree & 75 & 26,9 \\
Total & 279 & 100,0 \\
\hline
\end{tabular}


Table 7 Students' expectations for the acquisition of knowledge about plagiarism

\begin{tabular}{lll}
\hline I expect to learn more about how to avoid plagiarism during my university studies. & \\
\hline Completely disagree & Frequency & Percentage \\
Mostly disagree & 22 & 1,9 \\
Slightly disagree & 27 & 2,3 \\
Neutral & 38 & 3,2 \\
Slightly agree & 88 & 7,5 \\
Mostly agree & 147 & 12,6 \\
Completely agree & 255 & 21,8 \\
Total & 593 & 50,7 \\
\hline
\end{tabular}

Sigrell, 2016), and referencing skills (Itua, Coffey, Merryweather, Norton, \& Foxcroft, 2014; Vardi, 2012) for university students. Many authors have also said that students must acquire more knowledge about plagiarism prevention (Glendinning, 2014; Heckler, Forde, \& Bryan, 2013; Power, 2009).

Unfortunately, if we look at the professor's results, their expectations are in contradiction with the students'. There is a great divide between the two: while the professors expect the students to have these skills and knowledge prior to their entry at university, students expect to be trained by their professors. There is a distinct possibility that the students will not get the training they expect especially since certain authors already confirm that the teaching of informational skills (Shepherd \& Goggin, 2012), writing skills (Beaudet \& Rey, 2012) and referencing skill (Saunders, 2012) are not very present in university programs. Becquet and Étienne (2016) have mentioned that disciplinary skills and knowledge are prioritized in university over skills which are considered cross disciplinary.

When professors are asked about individual skills and knowledge, they expect students to be prepared for university, yet when asked if students are comfortable with academic writing in general, the level of agreement is a lot lower. Professors must then recognize that students need further training in order to be able to write in an academic style as well as to prevent plagiarism. In order to get professors to buy-in to this cross disciplinary training in their disciplinary courses, curriculums need to be restructured to have a program approach (Benharrat, 2018). This will ensure a coherent

Table 8 Professors' expectations of their students' knowledge about plagiarism

\begin{tabular}{lll}
\hline $\begin{array}{l}\text { As a teacher or lecturer, I expect undergraduate students to have learned how to avoid plagiarism during their } \\
\text { pre-university studies. }\end{array}$ & Frequency & Percentage \\
\hline Completely disagree & 6 & 2,2 \\
Mostly disagree & 10 & 3,6 \\
Slightly disagree & 10 & 3,6 \\
Neutral & 3 & 1,1 \\
Slightly agree & 27 & 9,7 \\
Mostly agree & 69 & 24,7 \\
Completely agree & 154 & 55,2 \\
Total & 279 & 100,0 \\
\hline
\end{tabular}


Table 9 Students' level of comfort with academic writing

\begin{tabular}{lll}
\hline Iam comfortable with academic writing in general. & & \\
\hline Completely disagree & Frequency & Percentage \\
Mostly disagree & 15 & 1,3 \\
Slightly disagree & 27 & 2,3 \\
Neutral & 42 & 3,6 \\
Slightly agree & 44 & 3,8 \\
Mostly agree & 131 & 11,2 \\
Completely agree & 554 & 47,4 \\
Missing & 334 & 28,5 \\
Total & 23 & 2,0 \\
\hline
\end{tabular}

approach to teaching the skills throughout the program and harmonization between the courses offered so that student training is progressive (Murray \& Nallaya, 2016). Activities, workshops, classes will be organized to answer the needs of the students for skills development and knowledge (Farrell \& Badke, 2015). For example, in a four-year program, certain skills will be taught in the first year, while others will build on these skills in the second year and so on. This way, all students will be developing informational, writing or referencing skills as well as plagiarism, taught by different professors over the four-year program.

\section{Teaching skills and knowledge to prevent plagiarism}

Most students arrive at university with some basic informational skills but research has shown that these are not sufficient (O'Sullivan \& Dallas, 2017). This is why, students still expect to be trained as shown in our results. What could professors teach them in a disciplinary course that would help them develop these skills and help them prevent plagiarism? Research has shown that many students need to diversify the navigational tools that they use (Georgas, 2014). Using a variety of navigational tools could be taught in the first year of a program while other skills, for example, evaluating sources or distinguishing between real and false news, could be taught afterwards (Kibirige \& DePalo, 2017). Yet again, Igo and Kiewra (2007, p. 527) state how students need to

Table 10 Professors' perceptions of their students' level of comfort with academic writing

\begin{tabular}{lll}
\hline \multicolumn{1}{l}{ My undergraduate students are comfortable with academic writing in general. } & \\
\hline Completely disagree & Frequency & Percentage \\
Mostly disagree & 30 & 10,8 \\
Slightly disagree & 48 & 17,2 \\
Neutral & 28 & 10,0 \\
Slightly agree & 12 & 4,3 \\
Mostly agree & 77 & 27,6 \\
Completely agree & 77 & 27,6 \\
Missing & 2 &, 7 \\
Total & 4 & 1,4 \\
\hline
\end{tabular}


learn how to take proper notes when searching the web, to be able to "engage in deeper mental processes" when reading their sources. All these are necessary skills to learn to prevent plagiarism in assignments.

As for writing skills, students absolutely need more training to be able to use paraphrasing and quoting in their assignments (Barry, 2006; Bronshteyn \& Baladad, 2006; McInnis, 2009). It is even more pertinent to learn about this in their own discipline as norms vary from one to the other (Maldoni, 2018; Murray \& Nallaya, 2016). Teaching this in a program approach, with lots of practice and feedback (Grohe, Schroeder, \& Davis, 2013), could certainly help prevent plagiarism (Maldoni, 2018).

Referencing skills need to be taught at university since high school students are often not required to provide references when using sources in their homework (Chanock, 2008; Williamson \& McGregor, 2011). Stevens (2016) reports how students have lots of difficulties writing their bibliographies as there exists many guidelines for the presentation norms (Escorcia, 2015). However, universities, whose mission is to develop skills, ethical values and integrity, (Gerstein \& Friedman, 2016) are the perfect environment for students to learn about referencing. The mechanics of referencing could be dealt with by teaching students, as early as in their first year of university, how to use a bibliography management software, Endnote or Mendeley for example, which very few students know how to use according to Milewski and Williamson (2017). Teaching students to recognize the importance of sources, how to integrate them coherently in their assignments would certainly help them understand the relevance and value of writing with integrity (Grohe et al., 2013).

Finally, in order to prevent plagiarism, students must be armed with knowledge about what it is (Brown \& Janssen, 2017). Research has shown that students are bewildered with what constitutes plagiarism or not (A. Palmer et al., 2019) and by the mixed signals they received from their professors (A. Palmer et al., 2019). Students would certainly benefit from clear directives and from knowing the expectations are the same from all the professors in their program (Grohe et al., 2013).

\section{Conclusion}

Most universities are actively trying to detect plagiarism. In an ideal world, all universities as a preventative measure, would implement program approaches that would teach all the skills and knowledge needed to promote academic integrity. However, students are reaching out, asking to be trained by the professors while in university. It is our mandate, our responsibility to close the gap between the level of skill and knowledge acquired before university and that required to succeed in university studies. We need to give our students the training they deserve so that they can leave our institutions and go out in the workforce with the skills and knowledge they need but also with knowing how to work with integrity.

It may be necessary to think realistically that it is not only professors who should take charge of teaching skills to avoid plagiarism. University curriculum developers and institutions also have a role to play because, on the one hand, they structure the training and exit profile of students and, on the other hand, it is the institutions that certify the degrees awarded. For the latter to have merit, every effort must be made to ensure that future generations of graduates develop their academic integrity. 
Authors' contributions

Both authors read and approved the final manuscript.

\section{Competing interests}

The authors declare that they have no competing interests.

Received: 11 June 2019 Accepted: 16 October 2019

Published online: 28 November 2019

\section{References}

American Association of School Librarians. (2007). Standards for the 21st-Century Learner. In (pp. 1-8). Chicago, II.: American Library Association

Amiri F, Razmjoo SA (2016) On Iranian EFL undergraduate students' perceptions of plagiarism. J Acad Ethics 14(2):115-131

Artman, M., Frisicaro-Pawlowski, E., \& Monge, R. (2010). Not just one shot: extending the dialogues about information literacy in composition classes. Composition Studies, 38(2), 93-110. Retrieved from https://search.ebscohost.com/login. aspx?direct=true\&db=eric\&AN=EJ944333\&lang=fr\&site=ehost-live http://www.compositionstudies.uwinnipeg.ca/archives/ 382.html

Association of College and Research Libraries. (2016). Référentiel de compétences informationnelles en enseignement supérieur. Retrieved from http://www.ala.org/acrl/sites/ala.org.acr/files/content/standards/framework-french.pdf (trad. du Groupe de travail de la Promotion du développement des compétences informationnelles (GT-PDCI))

Barry, E. S. (2006). Can paraphrasing practice help students define plagiarism? Coll Stud J, 40(2), 377-384. Retrieved from https://search.ebscohost.com/login.aspx?direct=true\&db=pbh\&AN=21375562\&lang=fr\&site=ehost-live

Bawden D (2001) Information and digital literacies: a review of concepts. J Doc 57(2):218-259 Retrieved from https://search. ebscohost.com/login.aspx?direct=true\&db=eric\&AN=EJ632998\&lang=fr\&site=ehost-live

Beaudet C (2015) Littéracie universitaire, patchwriting et impéritie. Le Français aujourd'hui 190(3):99-114

Beaudet, C., \& Rey, V. (2012). De l'écrit universitaire à l'écrit professionnel: comment favoriser le passage de l'écriture heuristique et scientifique à l'écriture professionnelle? Scripta, 16(30), 169-193

Becker BW (2016) Contemporary search behavior and the information age. Behav Soc Sci Libr 35(3):123-127. https://doi.org/ 10.1080/01639269.2016.1241121

Becquet, V., \& Étienne, R. (2016). Les compétences transversales en questions. Enjeux éducatifs et pratiques des acteurs Éducation et socialisation Les Cahiers du CERFEE (41)

Benharrat, A. (2018). Développer attention et motivation en stimulant la" prise de conscience": le cas de la formation documentaire à l'université. Paper presented at the Colloque international: Apprendre, Transmettre, Innover à et par I'Université Saison_2

Biddix JP, Chung CJ, Park HW (2011) Convenience or credibility? A study of college student online research behaviors. Internet High Educ 14(3):175-182

Brand-Gruwel S, Kammerer Y, van Meeuwen L, van Gog T (2017) Source evaluation of domain experts and novices during web search. Journal of Computer Assisted Learning 33(3):234-251. https://doi.org/10.1111/jcal.12162

Bronshteyn, K., \& Baladad, R. (2006). Perspectives on ... librarians as writing instructors: using paraphrasing exercises to teach beginning information literacy students. J Acad Librar, 32(5), 533-536. Retrieved from https://search.ebscohost.com/login. aspx?direct=true\&db=eric\&AN=EJ744251\&lang=fr\&site=ehost-live https://doi.org/10.1016/j.acalib.2006.05.010

Brown N, Janssen R (2017) Preventing plagiarism and fostering academic integrity: a practical approach. J Perspect Appl Acad Pract 5(3):102-109

Buckley, C. (2015). Conceptualising plagiarism: using Lego to construct students' understanding of authorship and citation. Teach High Educ, 20(3), 352-358

Burgess-Proctor, A., Cassano, G., Condron, D. J., Lyons, H. A., \& Sanders, G. (2014). A collective effort to improve sociology Students' writing skills. Teach Sociol, 42(2), 130-139. Retrieved from https://search.ebscohost.com/login.aspx?direct= true\&db=eric\&AN=EJ1021439\&lang=fr\&site=ehost-live https://doi.org/10.1177/0092055X13512458

Bury S (2011) Faculty attitudes, perceptions and experiences of information literacy: a study across multiple disciplines at York University, Canada. J Inform Literacy 5(1):45-64

Bury S (2016) Learning from faculty voices on information literacy: opportunities and challenges for undergraduate information literacy education. Ref Serv Rev 44(3):237-252. https://doi.org/10.1108/RSR-11-2015-0047

Catts R, Lau J (2008) Towards information literacy indicators

Chanock K (2008) When students reference plagiarised material-what can we learn (and what can we do) about their understanding of attribution? Int J Educ Integr 4(1)

Conole, G., de Laat, M., Dillon, T., \& Darby, J. (2008). 'Disruptive technologies', 'pedagogical innovation': What's new? Findings from an in-depth study of students' use and perception of technology. Comput Educ, 50(2), 511-524. doi:https://doi.org/ 10.1016/j.compedu.2007.09.009

Crockett L, Jukes I, Churches A (2011) Literacy is not enough. Corwin, Thousand Oaks, California

Cronin P, Ryan F, Coughlan M (2008) Undertaking a literature review: a step-by-step approach. Br J Nurs 17(1):38-43 Retrieved from https://search.ebscohost.com/login.aspx?direct=true\&db=rzh\&AN=105971907\&lang=fr\&site=ehost-live

DaCosta JW (2010) Is there an information literacy skills gap to be bridged? An examination of faculty perceptions and activities relating to information literacy in the United States and England. College Res Libraries 71(3):203-222. Retrieved from https://search.ebscohost.com/login.aspx?direct=true\&db=eric\&AN=EJ1057373\&lang=fr\&site=ehost-live. https://doi. org/10.5860/0710203

Dawes, L. (2017). Faculty perceptions of teaching information literacy to first-year students: a phenomenographic study. J Librariansh Inf Sci, 0961000617726129

Defazio J, Jones J, Tennant F, Hook SA (2010) Academic literacy: the importance and impact of writing across the curriculum--a case study. J Scholar Teaching Learning 10(2):34-47 Retrieved from https://search.ebscohost.com/login. aspx?direct=true\&db=eric\&AN=EJ890711\&lang=fr\&site=ehost-live 
Delcambre, I., \& Lahanier-Reuter, D. (2010). Les littéracies universitaires : Influence des disciplines et du niveau d'étude dans les pratiques de l'écrit. Forumlecture, 3. Retrieved from http:/wwww.leseforum.ch/fr/myUploadData/files/2010_3_Delcambre_Lahanier.pdf

Didier, C. (2017). Paroles d'enseignants sur l'écriture : recherche et institution en concurrence. Argumentation et Analyse du Discours, 19(19). doi:https://doi.org/10.4000/aad.2457

Dubicki E (2013) Faculty perceptions of students' information literacy skills competencies. J Inform Literacy 7(2):97-125

Duplessis P, Ballarini-Santonocito I (eds) (2007) Petit dictionnaire des concepts info-documentaires Approche didactique à l'usage des enseignants documentalistes. Savoirs CDI, Nantes

Escorcia D (2015) Teaching and assessing writing skills at university level: a comparison of practices in French and Colombian universities. Educ Res 57(3):254-271

Farrell R, Badke W (2015) Situating information literacy in the disciplines: a practical and systematic approach for academic librarians. Ref Serv Rev 43(2):319-340

Fenton-Smith B, Humphreys P, Walkinshaw I, Michael R, Lobo A (2017) Implementing a university-wide credit-bearing English language enhancement programme: issues emerging from practice. Stud High Educ 42(3):463-479

Foster, D. (2002). Writing and learning in cross-national perspective: Transitions from secondary to higher education: Routledge

Georgas, H. (2014). Google vs. the library (part II): student search patterns and behaviors when using Google and a federated search tool. Portal: Libraries and the Academy, 14(4), 503-532

Gerstein, M., \& Friedman, H. H. (2016). Rethinking higher education: Focusing on skills and competencies. Gerstein, Miriam and Hershey H. Friedman (2016),"Rethinking higher education: focusing on skills and competencies," Psychosociol Issues Hum Resour Manag, 4(2), 104-121

Glendinning I (2014) Responses to student plagiarism in higher education across Europe. Int J Educ Integr:10

Goldenstein, C., \& Kearley, J. (2013). Faculty perceptions of library instruction. Paper presented at the of the 10th northumbria international conference on performance measurement in libraries and information services

Goldschmidt M (2014) Teaching writing in the disciplines: student perspectives on learning genre. Teaching Learning Inquiry 2(2):25-40

Gravett K, Kinchin IM (2018) Referencing and empowerment: exploring barriers to agency in the higher education student experience. Teaching in Higher Education:1-14

Grohe B, Schroeder J, Davis SR (2013) Using online resources to improve writing skills and attitudes about writing and plagiarism of criminal justice students. J Excell Coll Teach 24(1)

Harris A (2016) Integrating written communication skills: working towards a whole of course approach. Teach High Educ 21(3):287-300

Harris, R. (2013). Evaluating Internet Research Sources. Retrieved from http://www.virtualsalt.com/evalu8it.htm

Hayes JR, Flower LS (1980) Identifying the organization of writing processes. In: Gregg LW, Steinberg ER (eds) Cognitive processes in writing. Lawrence Erlbaum, Hillsdale, NJ, pp 3-30

Head A, Eisenberg M (2010) Truth be told: how college students evaluate and use information in the digital age

Heckler NC, Forde DR, Bryan CH (2013) Using writing assignment designs to mitigate plagiarism. Teach Sociol 41(1):94-105 Retrieved from http://mandataire.uqo.ca:2098/stable/41725583

Holt, E. A. (2012). Education improves plagiarism detection by biology undergraduates. Bioscience, 62(6), 585-592. Retrieved from https://search.ebscohost.com/login.aspx?direct=true\&db=eric\&AN=EJ970884\&lang=fr\&site=ehost-live https://doi.org/ 10.1525/bio.2012.62.6.9

Howard RM (1995) Plagiarism, authorship, and the academic death penalty. Coll Engl 57(7):788-806

Hutchings C (2014) Referencing and identity, voice and agency: adult Learners' transformations within literacy practices. High Educ Res Dev 33(2):312-324. Retrieved from https://search.ebscohost.com/login.aspx?direct=true\&db=eric\&AN=EJ102452 8\&lang=fr\&site=ehost-live. https://doi.org/10.1080/07294360.2013.832159

Hyland K (2015) Teaching and researching writing: Routledge

Igo LB, Kiewra KA (2007) How do high-achieving students approach web-based, copy and paste note taking? J Adv Acad 18(4):512-529

Isaacs, E., \& Knight, M. (2014). A Bird's eye view of writing centers: institutional infrastructure, scope and programmatic issues, reported practices. WPA: Writing Program Administration-Journal of the Council of Writing Program Administrators, 37(2)

Itua I, Coffey M, Merryweather D, Norton L, Foxcroft A (2014) Exploring barriers and solutions to academic writing: perspectives from students, higher education and further education tutors. J Furth High Educ 38(3):305-326. https://doi. org/10.1080/0309877X.2012.726966

Janssens, K., \& Tummers, J. (2015). A pilot study on students' and lecturers' perspective on plagiarism in higher professional education in Flanders. Plagiarism Across Europe and Beyond, 12-24

Jeffrey, L., Hegarty, B., Kelly, O., Penman, M., Coburn, D., \& McDonald, J. (2011). Developing digital information literacy in higher education: obstacles and supports. J Inf Technol Educ, 10, 383-413.

Julien H, Gross M, Latham D (2018) Survey of information literacy instructional practices in US academic libraries. College Res Libraries 79(2):179

Kargbo JA (2010) Undergraduate Students' problems with citing references. Ref Libr 51(3):222-236. https://doi.org/10.1080/ 02763871003769673

Kibirige HM, DePalo L (2017) The internet as a source of academic research information: findings of two pilot studies. Inf Technol Libr 19(1):11-16

Kissel F, Wininger MR, Weeden SR, Wittberg PA, Halverson RS, Lacy M, Huisman RK (2016) Bridging the gaps: collaboration in a faculty and librarian community of practice on information literacy. University Press of Colorado, In

Lea MR (2004) Academic literacies: a pedagogy for course design. Stud High Educ 29(6):739-756. https://doi.org/10.1080/ 0307507042000287230

Leeder C, Shah C (2016) Library research as collaborative information seeking. Library Inform Sci Res 38(3):202-211. https:// doi.org/10.1016/j.lisr.2016.08.001

Liardét, C., \& Black, S. (2016). 'According to...': Analysing learner development of referencing and evidence integration. Eng Aust J, 31(2), 45 
Mackey TP, Jacobson TE (2011) Reframing information literacy as a Metaliteracy. College Res Libraries 72(1):62-78. https://doi. org/10.5860/crl-76r1

Maldoni AM (2018) "Degrees of deception" to degrees of proficiency: embedding academic literacies into the disciplines. J Acad Lang Learning 12(2):A102-A129

Mandernach BJ, Zafonte M, Taylor C (2016) Instructional strategies to improve college Students' APA style writing. Int J Teaching Learning Higher Educ 27(3):407-412 Retrieved from https://search.ebscohost.com/login.aspx?direct=true\&db= eric\&AN=EJ1093747\&lang=fr\&site=ehost-live

McGowan S, Lightbody M (2008) Enhancing Students' understanding of plagiarism within a discipline context. Account Educ Int J 17(3):273-290

McGrath L, Kaufhold K (2016) English for specific purposes and academic literacies: eclecticism in academic writing pedagogy. Teach High Educ 21(8):933-947

McInnis, L. (2009). Analyzing English L1 and L2 paraphrasing strategies through concurrent verbal report and stimulated recall protocols. (Master of arts). University of Toronto, Toronto

Medvedeva M, Recuber T (2016) Developing an original argument: a strategy for college writing. Coll Teach 64(3):139-144. https://doi.org/10.1080/87567555.2015.1125841

Milewski SD, Williamson JM (2017) Developing a reflective practice template for citation management software instruction. Ref User Serv Q 57(1):6-11 Retrieved from https://search.ebscohost.com/login.aspx?direct=true\&db=IIs\&AN=125571425 \&lang=fr\&site $=$ ehost-live

Moore JL, Rosinski P, Peeples T, Pigg S, Rife MC, Brunk-Chavez B et al (2016) Revisualizing composition: how first-year writers use composing technologies. Comput Compos 39:1-13

Murray N, Nallaya S (2016) Embedding academic literacies in university programme curricula: a case study. Stud High Educ 41(7):1296-1312

Nelson K, Courier M, Joseph GW (2011) Teaching tip an investigation of digital literacy needs of students. J Inf Syst Educ 22(2):95-109 Retrieved from https://search.ebscohost.com/login.aspx?direct=true\&db=Ils\&AN=66339172\&lang=fr\&site= ehost-live

Newton P (2016) Academic integrity: a quantitative study of confidence and understanding in students at the start of their higher education. Assess Eval High Educ 41(3):482-497

O'Sullivan MK, Dallas KB (2017) A collaborative approach to implementing 21st century skills in a high school senior research class. Educ Libr 33(1):3-9

Ovadia S (2010) Writing as an information literacy tool: bringing writing in the disciplines to an online library class. J Libr Adm 50:899-908

Palmer A, Pegrum M, Oakley G (2019) A wake-up call? Issues with plagiarism in transnational higher education. Ethics Behav 29(1):23-50

Palmer, L., Levett-Jones, T., \& Smith, R. (2018). First year students' perceptions of academic literacies preparedness and embedded diagnostic assessment. Student Success, 9(2), 49-61

Pecorari, D. (2015). Plagiarism in second language writing: is it time to close the case

Pelger, S., \& Sigrell, A. (2016). Rhetorical meta-language to promote the development of Students' writing skills and subject matter understanding? Journal of Second Language Writing, 30, 94-99. Doi:https://doi.org/10.1016/j.jslw.2015.08.003. Res Sci Technol Educ, 34(1), 25-42. Retrieved from https://search.ebscohost.com/login.aspx?direct=true\&db=eric\&AN=EJ1 088629\&lang=fr\&site=ehost-live https://doi.org/10.1080/02635143.2015.1060410

Peters M (2015) Enseigner les stratégies de créacollage numérique pour éviter le plagiat au secondaire. (French). Can J Educ 38(3): 1-28 Retrieved from https:/search.ebscohost.com/login.aspx?direct=true\&db=eue\&AN=1 10208958\&lang=fr\&site=ehost-live

Peters M, Boies T, Morin S (in press) Teaching academic integrity in Quebec universities: roles professors adopt

Peters, M., \& Gervais, S. (2016). Littératies et créacollage numérique. Language and Literacy, 18(2), 62-78

Peters, M., Vincent, F., Fontaine, S., \& Fiset-Vincent, C. (2018). Validation d'un questionnaire sur les stratégies de créacollage numérique d'étudiants universitaires québécois. Revue internationale des technologies en pédagogie universitaire, 15(1), 45-60

Peters M, Vincent F, Gervais S, Morin S, Pouliot J-P (2019) Les stratégies de créacollage numérique et les compétences requises pour les mobiliser. In: Karsenti T (ed) Le numérique en éducation: Pour développer des compétences. PUQ, Québec, pp 185-206

Peters M, Weinberg A, Sarma N, Frankoff M (2011) From the mouths of Canadian University students: web-based information-seeking activities for language learning. CALICO J 28(3):621-638

Power, L. G. (2009). University students' perceptions of plagiarism. J High Educ, 80(6), 643-662

Prentice FM, Kinden CE (2018) Paraphrasing tools, language translation tools and plagiarism: an exploratory study. Int J Educ Integr 14(1):11. https://doi.org/10.1007/s40979-018-0036-7

Probert E (2009) Information literacy skills: teacher understandings and practice. Comput Educ 53:24-33

Ramdhani A, Ramdhani MA, Amin AS (2014) Writing a literature review research paper: a step-by-step approach. Int J Basic App Sci 3(1):47-56

Rekdal OB (2014) Academic citation practice: a sinking sheep? Portal: Libraries and the Academy 14(4):567-585. Retrieved from https://search.ebscohost.com/login.aspx?direct=true\&db=eric\&AN=EJ1044243\&lang=fr\&site=ehost-live. https://doi. org/10.1353/pla.2014.0025

Richards K, Pilcher N (2018) Academic literacies: the word is not enough. Teach High Educ 23(2):162-177

Rodicio, H. G. (2015). Students' evaluation strategies in a web research task: are they sensitive to relevance and reliability? J Comput Higher Educ, 27(2), 134-157. Doi:https://doi.org/10.1007/s12528-015-9098-1

Rogerson AM, McCarthy G (2017) Using internet based paraphrasing tools: original work, patchwriting or facilitated plagiarism? Int J Educ Integr 13(1):2. https://doi.org/10.1007/s40979-016-0013-y

Roy, R. (2009). Enquête génération C - CEFRIO 2009 Les utilisateurs 12-24 ans: utilisateurs extrêmes d'Internet et des TI. Réseau CEFRIO, 7(1), 3-5

Salem J, Fehrmann P (2013) Bibliographic management software: a focus group study of the preferences and practices of undergraduate students. Public Services Quarterly 9(2):110-120. https://doi.org/10.1080/15228959.2013.785878

Saunders L (2012) Faculty perspectives on information literacy as a student learning outcome. J Acad Librariansh 38(4):226236. https://doi.org/10.1016/j.acalib.2012.06.001 
Serres A (2012) Dans le labyrinthe : évaluer l'information Sur internet. C\&F éditions, Caen

Shao X, Purpur G (2016) Effects of information literacy skills on student writing and course performance. J Acad Librariansh 42(6):670-678

Shepherd R, Goggin P (2012) Reclaiming" old" literacies in the new literacy information age: the functional literacies of the mediated workstation. Composition Studies 40(2):66

Shi L (2010) Textual appropriation and citing behaviors of university undergraduates. Appl Linguis 31(1):1-24. Retrieved from https://search.ebscohost.com/login.aspx?direct=true\&db=eric\&AN=EJ872596\&lang=fr\&site=ehost-live. https://doi.org/10. 1093/applin/amn045

Simonnot B (2007) Évaluer l'information. Documentaliste-Sciences de l'Information 44:210-216. https://doi.org/10.3917/docsi. 443.0210

Steeves, V. (2014). Jeunes Canadiens dans un monde branché, Phase III : Experts ou amateurs? Jauger les compétences en littératie numérique des jeunes Canadiens. Retrieved from Ottawa: http://habilomedias.ca/sites/default/files/pdfs/ publication-report/full/JCMBIII_Experts_amateurs_Rapport.pdf

Stevens CR (2016) Citation generators, OWL, and the persistence of error-ridden references: an assessment for learning approach to citation errors. J Acad Librariansh 42(6):712-718. https://doi.org/10.1016/j.acalib.2016.07.003

Strangfeld JA (2019) I just Don't want to be judged: cultural Capital's impact on student plagiarism. SAGE Open 9(1): 2158244018822382

Sutherland-Smith W (2018) Is student plagiarism still a serious problem in universities today? In: Pecorari D, Shaw P (eds) Student plagiarism in higher education. Routledge, London, pp 47-61

Tassin, A., \& Spanghero-Gaillard, N. (2017). Le développement des habiletés rédactionnelles à l'université : expertise discursive et acculturation aux discours universitaires. Retrieved from http://journals.openedition.org/linx/1648

Vardi I (2012) Developing students' referencing skills: a matter of plagiarism, punishment and morality or of learning to write critically? Higher Educ Res Development 31(6):921-930

Williamson K, McGregor J (2011) Generating knowledge and avoiding plagiarism: smart information use by high school students. School Library Media Res 14:1-22 Retrieved from https://search.ebscohost.com/login.aspx?direct=true\&db= eue\&AN=126492669\&lang=fr\&site=ehost-live

Wingate U (2006) Doing away with 'study skills'. Teach High Educ 11(4):457-469. https://doi.org/10.1080/13562510600874268

Wingate U, Tribble C (2012) The best of both worlds? Towards an English for academic purposes/academic literacies writing pedagogy. Stud High Educ 37(4):481-495. https://doi.org/10.1080/03075079.2010.525630

Wischgoll A (2016) Combined training of one cognitive and one metacognitive strategy improves academic writing skills. Front Psychol 7:187

\section{Publisher's Note}

Springer Nature remains neutral with regard to jurisdictional claims in published maps and institutional affiliations.

Ready to submit your research? Choose BMC and benefit from:

- fast, convenient online submission

- thorough peer review by experienced researchers in your field

- rapid publication on acceptance

- support for research data, including large and complex data types

- gold Open Access which fosters wider collaboration and increased citations

- maximum visibility for your research: over $100 \mathrm{M}$ website views per year

At $B M C$, research is always in progress.

Learn more biomedcentral.com/submissions 